\title{
CORRELATION BETWEEN FACEBOOK USE, MENTAL HEALTH AND LEARNING ENGAGEMENT: A CASE OF UNIVERSITIES IN SURABAYA CITY, INDONESIA
}

\author{
Dr. Baraka Manjale NGUSSA \\ ORCID: 0000-0001-5527-9924 \\ School of Education \\ University of Arusha \\ Arusha, TANZANIA \\ Fifi Khoirul FITRIYAH \\ ORCID: 0000-0002-4087-0022 \\ Faculty of Teacher Training and Education \\ Universitas Nahdlatul Ulama Surabaya \\ Surabaya, INDONESIA \\ Syaiputra Wahyuda Meisa DININGRAT \\ ORCID: 0000-0003-4529-9168 \\ Department of Islamic Early Childhood Education \\ STIT Al-lbrohimy Bangkalan \\ Bangkalan, INDONESIA
}

Received: 05/04/2020 Accepted: 28/05/2020

\begin{abstract}
This study was propelled by the Covid 19 Global Pandemic which necessitates online platforms to replace traditional classrooms than ever before. The study investigated on the perception on and interrelationships between Facebook use, mental health and engagement in learning. Using Descriptive Correlational Design, the study used online questionnaire to collect data from a convenient sample of 253University students with varied demographic characteristics in Surabaya City. The mean age of respondents was 21.5. Cronbach's Alpha of above 0.7 was established for each variable prior to data analysis. The study established that students did not consider Facebook as a valuable platform for learning. Difference in Facebook use by gender and area of study was not significant. Students' preferred platforms included Google classroom, WhatsApp and Zoom. Students experienced anxiety and it was not easy for them to cope up with stressful moments. However, they concentrated in learning without any interference from Facebook and took active role in extra-curricular activities, sports and games. Mental health positively influenced students' engagement while Facebook use enhanced mental health. Therefore, it is recommended that educators should make use of Google Classroom, WhatsApp and Zoom to support students' engagement. Students need to actively engage in sports and games to overcome potential stressful moments. Educators should take advantage of students' engagement by introducing alternative social media platforms for further enhancement of learning engagement. Finally, Education stakeholders need to enhance mental health education in order to increase rates of students' engagement in learning.
\end{abstract}

Keywords: Facebook, Social media, mental health, engagement, learning, Covid 19, Indonesia.

\section{INTRODUCTION}

Covid 19 Global Pandemic has highly necessitated online learning means to replace traditional learning approaches whereby the teacher must meet the learners face to face at a certain locality in the classroom. While most governments around the world have temporarily closed educational institutions in an attempt to contain the spread of the COVID-19 pandemic, these nationwide closures are impacting over $89 \%$ of the 
world's student population (UNESCO Covid 19 Educational Disruption and Response, 2020). Burgess and Sievertsen (2020) consider the COVID-19 pandemic as first and foremost health crisis. As many countries have decided to close schools, colleges and universities, the crisis crystallises the dilemma policymakers are facing between closing schools to reduce contact and saving lives and keeping them open by allowing workers to work and maintaining the economy. While numerous countries in the world have suspended traditional face to face meetings including face to face classrooms in fear of massive spread of the Covid 19 pandemic, there is a serious need for educators and researchers to find out most appropriate alternative means to meet the learners at the points of their needs. In response to this need, this study sought to investigate on the correlation between Facebook use, mental health and students' engagement in learning in order to come up with appropriate recommendations to students, parents, educators, education administrators, policy makers and other higher education stakeholders.

In the $21^{\text {st }}$ century, the use of social media is the closest life to society in all of development ages. Social network has influenced the lives of young people and penetrated into many fields including the field of education. In particular, Facebook is used by millions of people for various activities including teaching and learning. In recent times, Facebook has become one of the most important communication platforms through which young people can easily interact in both personal and academic issues. In particular, some students and educators around the world utilize Facebook into the instructional process as a communication tool (Al-rahmi, 2013). Its roles include sharing ideas, collaboration between faculty and students as well as facilitating and acquiring knowledge (Al-Khalifa \& Garcia, 2013). Studies have shown the effect of social media platforms on academic performance, interaction and participation of students in the teaching and learning transaction. The study of (Al-Khalifa \& Garcia, 2013), for instance, revealed a significant positive relationship between Telegram usage and students' learning engagement. The study of (Sharma, Joshi, \& Sharma, 2016)thus supporting Vygotsky's socio constructivist approach. The aim of this paper is to predict key determinants that affect students' intention towards academic use of Facebook. The usable data were gathered from 215 Omani students, and multi-analytical methods were employed to test the proposed research model. The results obtained from structural equation modeling (SEM further outlined possible key factors that may affect students' intention to use social media for academic matters. The study revealed that resource sharing was the most influencing factor in the decision to use Facebook in higher education, followed by personal usefulness, enjoyment, collaboration and social influence.

Usefulness of Facebook in academic arena can be seen in the fact that about $91.1 \%$ of students in African countries, for example, use social media, Facebook included, for learning purpose (Mirembe, Lubega, \& Kibukamusoke, 2020). Several previous research found that Facebook is highly recommended in learning in various countries, including for distance learning by involving interactions in Facebook groups (Baggaley, 2012; Lenandlar, 2013; Lim, 2010). Likewise, Indonesia has witnessed a tremendous growth in social media usage in various aspects of life. According to Internet World State (2018), Indonesia, is the $4^{\text {th }}$ country in the world with the highest Facebook user having 130 million users. In particular, records show that Facebook is the most used social media among English teachers in Indonesia (Rafidiyah\& Bayeck, 2016). Form the Indonesian teachers' perspective, the study of Patahuddin, Rokhmah and Lowrie, (2020) highlights the affordance of Facebook in providing opportunity for members to connect not only with friends but also with professionals across the country, in sharing expertise, practices, and ways of thinking. In addition, a recent study in private Indonesian universities showed that Facebook groups have potential to be used as online tutorial complement in which there are pedagogical, social and technological affordances for sharing ideas and resources as well as implementing online discussions. However, although most faculty members were aware of the benefit Facebook in teaching and learning and they used a range of social media platforms for various personal and professional courses, they were reluctant to use it in the classroom (Inayati, 2015) Malang, Indonesia. She obtained her Master of Education from the University of Adelaide, Australia. She has published several textbooks and research papers, and presented in several conferences. Her research interest is in technology and independent learning in ELT. Social media technology (SMT. This could be due to availability of multiple social media platforms like Twitter, Instagram and others which can be used for the same purpose.

While studies have revealed usefulness of Facebook in both personal and academic arena, other studies have indicated possible negative effects of Facebook especially when it is overused (Brailovskaia, Margraf, 
Schillack, \& Kollner, 2019). The study of Rahman and Ahmed (2018) at Chitagong University, for instance, revealed that while female students spent more time on Facebook than males, significant correlations existed among Facebook use, Facebook addiction, and mental health. Particularly, Facebook use and addiction both negatively predicted the mental health. According to Nazzal, Rebee, Baara and Berte (2018), dependence on social media is suggested to diminish motivation to participate in naturally occurring activities and life interests, leading to physical and mental health risks. The study of Pantic (2014) further revealed that while prolonged use of social networking sites such as Facebook may be related to signs and symptoms of depression, the relationship between Social Network use and mental problems remains controversial. Therefore, the apparent diminishing motivation to participate in naturally occurring activities due to Facebook usage has triggered the present researchers to find out whether Facebook use affects students' mental health and learning engagement in traditional classrooms in the context of Indonesian universities. This study therefore, sought to establish the interrelationship between Facebook use, mental health and student engagement in the teaching and learning transaction. The researchers consulted various sources including journal articles and books to throw more light on the variables under investigation.

\section{THE CONCEPT OF ENGAGEMENT IN LEARNING}

One important learning outcome variables related to attributes of social networking services is engagement. Due to this, educational research has increasingly highlighted the importance of student engagement and its impact on student's retention and learning. Even though engagement is pivotal in learning effectiveness, it is difficult to provide a clear definition of it. Generally, engagement can be seen as the quality of a student connection or involvement with the endeavor of schooling and hence with the people (Skinner, Kindermann, and Furrer, (2009). Specifically, different authors have attempted to define the term in various ways. According to Nasional Survey of Student Engagement (2002), for instance, engagement can be referred to as the intersection of time and energy students devote to involve in productive learning activity. Newmann, Wehlage, and Lamborn (1992) in Martin and Boliger (2018) consider it as "the student's psychological investment in and effort directed toward learning, understanding or mastering the knowledge, skills, or crafts that academic work is intended to promote." The term is further regarded by Csikszentmihalyi (1990) in Taylor and Pearson (2011, p. 67) as "a growth-producing activity through which an individual allocates attention in active response to the environment." The current study considers it as the time and effort invested by students in participating in the moment, task, or learning activity.

Engagement is a key ingredient for learning effectiveness. This fact is built on a constructivism theory which states that the learner is a key person in the teaching and learning transactions (Ngussa and Ndiku, 2014). According to Taylor and Pearson (2011, p. 27), "student engagement has primarily and historically focused upon increasing achievement, positive behaviors and a sense of belonging in students so they might remain in school. Therefore, it is essential for teachers and administrators in higher learning institutions to ensure that students are highly engaged in the teaching and learning process to guarantee presence and maximized performance. Hart, Stewart and Jimerson (2011, p. 67) have it that "student engagement in school is an important construct that has been associated with student success." Furthermore, Martin and Boliger (2018, p. 205), add that "student engagement increases student satisfaction, enhances student motivation to learn, reduces the sense of isolation, and improves student performance in online courses."

Even though engagement is relatively diverse, the dimension of behavioural, emotional, and cognitive engagement is employed to measure the student's engagement in learning (Fredricks \& McColskey, 2012). Behavioural engagement draws on the idea of participating and includes involvement in academic, social, or extracurricular activities. It is considered crucial for achieving positive academic outcomes. While emotional engagement focuses on the extent of positive and negative reactions to teachers, classmates, academic or school, cognitive engagement is the student's level of investment in learning. Indicators for behavioural engagement include directly observable attendance and participation in curricular and extracurricular tasks. Indicator for cognitive engagement includes asking questions for clarification of ideas, persistence in difficult activities, flexibility in problem-solving, use of learning strategies and use of self-regulation to support learning. The emotional engagement, on the other hand, includes indicators such as presence of interest and happiness and the absence of boredom, anxiety, and sadness, a sense of identification and belonging to 
school, value school outcome and feelings as though the learners are supported by their peers and teachers (Alrashidi, Phan, \& Ngu, 2016; Fredricks \& McColskey, 2012).

Studies have indicated various factors that may be associated with students' engagement in learning. One of the most identified factors is mental health. According to Jonynien and Kern (2012) in Alhabees, Alsaida and Alhabees (2018), mental health is a state of psychological contentment, or the condition when there is no mental illness. It is the psychological state of someone who is functioning at a satisfactory level of emotional level and behavioural adjustment." This definition alone tells how mental health can be a determining factor in learning effectiveness whose prerequisite is engagement. When students are characterized with effective mental health, their rates of engagement in the teaching and learning process is likely to be maximized. According to Substance Abuse and Mental Health Services Administration (2005 and World Health Organization (2005) in Swaner (2007, p. 1), "like the concept of engaged learning, "mental health" and "well-being" ... are broadly described in the literature as encompassing individuals' abilities to realize their potential, cope with stress, relate positively with others, make healthy decisions, and contribute to community." According to Suldo, Gormley, DuPaul and Anderson-Butcher (2013), while students' mental health and academic outcomes are different domains of functioning, they are closely interrelated. They particularly argue that despite most educators' primary focus on academic learning and indicators of achievement, attention to student mental health is highly needed because mental health affects academic outcomes, academic achievement affects mental health and therefore since the mission of schools involves developing competent citizens, a dual focus on mental health and academic outcomes is highly needed.

Apart from Mental health, availability, use and usefulness of modern technology can be another factor which may determine the rate of students' engagement in learning. This fact is based on the constructivism theory which holds that the more the learners are exposed to practical employment of teaching and learning resources, the more they get engaged in the teaching and learning process (Ngussa and Abel, 2017). Particularly, the use of social media platforms such as Facebook can be a specific factor that can enhance or hinder learners' engagement in the teaching and learning process. Particularly, while effective use of Facebook can support learning engagement, when Facebook is overused or misused, it may lead into students' disengagement in the learning process. The overuse of Facebook by learners brings about a likelihood of students getting exhausted as well as experiencing a situation of burning eyes, disturbed sleep and headache (Jha, Shah, Basnet, et al, 2016). While these conditions may cause absence from the classroom while the teaching and learning process takes place, the rate of engagement in learning can be negatively affected.

\section{FACEBOOK USE AND LEARNING ENGAGEMENT}

Social media networks have created conducive atmosphere for learning to take place beyond traditional classroom. According to Bahati (2015, p. 160), "when face-to-face lecture sessions and classroom seminars are conducted during hours and days that are not convenient to students, the level of student active engagement and participation is considerably reduced." In the contemporary time when online learning competes with traditional modalities of teaching and learning, which are basically characterized with physically attendance at the teaching-learning site, technology has played great deal in expanding avenues for studying without physical contact between the teacher and the learner. In this attempt, Facebook is one of most widely used social media platforms in day to day activities. It is the most popular social networking tool among university-aged youths and its popularity has suited it for educational purposes (Dheleai and Tasir, 2017). According to Eroglu (2016), while social networking sites are becoming one of the most frequently used online communication types in the world, Facebook is one of the commonly used social networking for teaching, learning and other activities.

Studies have indicated the power of Facebook on the life of modern young people. According to Debatin and Lovejoy (2009, p. 83), "student life without Facebook is almost unthinkable. Since its inception in 2004, this popular social network service has quickly become both a basic tool for and a mirror of social interaction, personal identity and network building among students." By July 2016, Facebook had more than 1.71 billion active users per month, with 1.1 billion log-ins every day. It has been estimated that the average American spends approximately 40 minutes per day on Facebook and approximately 50\% of 18-24 year-olds visit Facebook as soon as they wake up (Chakraborty, 2016). 
Studies have thrown light on the rate of Facebook usage for academic purposes. Jha, Shah, Basnet, et al (2016), for instance, investigated on Facebook use and its effects on the life of health science students in a private medical college of Nepal and came up with the findings that the main reason for using Facebook was to remain in contact with family and friend (32\%) while its use for the academic purpose was only $5 \%$. This suggests that the use Facebook use trend by university students is majorly on social networking rather than on learning. Further, while $80.8 \%$ of students under investigation acknowledged ease in acquiring academic materials from others through Facebook, one-fourth of respondents indicated that they use Facebook late at night on a regular basis. Surprisingly, $4.2 \%$ of respondents admitted accessing Facebook for personal issues during the classroom lectures when the teaching learning activities are taking place. This is one of potential negative effects of Facebook usage toward learning engagement.

According to Saleh, Abdul and Ameen (2017, p. 7597), while some students suffer from using Facebook because of being addicted to it, Facebook still occupies an important part of people's time and life due to the recent developments in the field of communication technologies." This implies that like any other social media platform, Facebook must have positive and negative effect on the users. According to Wanjohi, Mwebi and Nyang'ara (2015), the use of social media platforms, Facebook included, has a potential effect on the productivity of the users in their places of work, at schools and in the society. Most recent study findings by Murad, Gul, Changezi, Naz and Khan (2019) from undergraduate students of Quetta City indicate that Facebook has infiltrated the 21st-century generations of Internet users, making it a very active means of communications among students of higher education. Particularly, Facebook plays an important role in a student's daily life, thus having great impact on academic performance. Specific established positive effect of Facebook technology includes gaining a lot of information through it, easy communication with teachers and fellow learners as well as maximized interaction with learning peers.

Studies have further revealed the power of Facebook toward maximized engagement in learning. Findings of Dheleai and Tasir (2017), for instance, revealed that university students had positive views towards the use of Facebook for online interaction with peers. Specifically, the findings revealed a positive relationship between students' perceived online interaction via Facebook and academic performance. According to Moghavvemi, Sulaiman, Aziz and Way (2017), University students admitted to have used Facebook technology for entertainment, relaxing and passing time. They also affirmed that spending time on Facebook had a positive effect on their academic performance, thus, concluding that time spent on Facebook did not affect quality of their education.

On the contrary, other studies have revealed negative effect of Facebook usage on the learners. According to Jha, Shah, Basnet, et al (2016), negative effects of excessive Facebook usage includes burning eyes, disturbed sleep and headache. Apart from physical and mental effect, Facebook usage has other negative effect on academic performance. This is seen in findings of Rouis, Limayem and Salehi-Sangari (2011), who investigated on impact of Facebook usage on students 'academic achievement in the context of selfregulation and trust and came up with the findings that extensive use of Facebook by university students with extraverted personalities leads to poor academic performance. However, the study also revealed that students who are more self-regulated control their presence on Facebook more effectively, thus getting rid of possible detrimental effects from the platform. This suggests that the negative effect from Facebook usage depends on approaches employed on its use.

\section{MENTAL HEALTH AND LEARNING ENGAGEMENT}

Mental health is defined as a person's ability to endure stressful conditions by increasing productivity (Fusarpoli et al., 2019). Mental health management in a country is inseparable from government policies in supporting mental health services (Petrea et al., 2019). This has led nations to spend significant amount is their budgets to ensure mental health of citizens. In European countries, for instance, handling mental health is given a portion of the budget of $2.3 \%$ outside the research budget on mental health. Yet, study findings claim that funds for overcoming chronic mental health conditions in the countries for managing mental health disorders are still lacking (Castelpietra et al., 2020). This leads parents to get worried about status of mental health of their children in schools. Parents in Latin, for example, experience worries for their children aged 6-13 years with regard to their mental health. This is due to the difficulty they face in 
identifying mental health problems in their children. On the other hand, those parents who are aware of the mental health problem, play an active role in seeking mental health services (Dixon De Silva, Ponting, Ramos, Cornejo Guevara, \& Chavira, 2020).

Therefore, mental health study findings are essential for parents, who are key school stakeholders, for them to play their roles effectively in guiding and counseling their children in order to improve their mental health. Some examples of suggested techniques for improving mental health include mental health literacy, attitudes toward mental disorders, perception and self-values, cognitive skills, academic and work performance, emotion management, appropriate behavior, self-management strategies, social skills, appropriate family relationships, physical health, sexual health and meaningful of life (Fusar-poli et al., 2019). Other strategies in improving mental health in students include engage in physical activities and sports (deJonge, Omran, Faulkner, \& Sabiston, 2020). It is also important to note that implementation of elective mental health courses positively improves the mental health of students especially in the aspect of self-confidence (Robinson, Maslo, McKeirnan, Kim, \& Brand-Eubanks, 2020). Implications of Sexual Assault Referral Centers (SARCs) in the UK was also observed to have an impact on improving the mental health of victims of sexual violence (Brooker, Hughes, Lloyd-Evans, \& Stefanidou (2019); (deJonge et al., 2020). Therefore, guidance and counseling regarding sex and sexuality have great deal in supporting mental health of the youths.

Further, the essence of studying mental health in relation to academic issue is in that conducting activities with a compulsion worsens a person's productivity, yielding to limited learning engagement (Lowe, 2020). Specifically, when appropriate mental health is lacking to learners in higher learning institutions, negative outcomes are likely to take place. A study of Lindow et al., (2020) indicates that unstable mental health may result into high number in suicides. This is further evidenced by study findings of Choo, Chew and Ho (2018) that when three years of medical records related to suicide attempters $(\mathrm{N}=462)$ admitted to the emergency department of a large teaching hospital in Singapore were subjected to analysis, $25 \%$ were diagnosed with mental illness. Of these, $70.6 \%$ were females while $29.4 \%$ were males; National wise, $62.6 \%$ were from China, $15.4 \%$ were Malays and $16.0 \%$ were Indians. This suggests that mental health is a serious issue that cuts across demographic differences among students in higher learning institutions. It is also evidenced that mental health disorders can influence violence and crime cases in the society (Halle, TzaniPepelasi, Pylarinou, \& Fumagalli, 2020). Therefore, it is essential to ensure that higher learning institutions become aware of factors that positively influence mental health and act accordingly to boost the students' mental health condition.

Study findings have mentioned several factors that affect mental health condition negatively. These include financial distress (Frankham, Richardson, \& Maguire, 2020), failure to finish studies and graduate on time (Avendano, de Coulon, \& Nafilyan, 2020), stress (Lowe, 2020), peer pressure from neighborhood (Wallace \& Wang, 2020) and career adaptation (Xu et al., 2020). Likewise, other studies have indicated a close connection between mental health and the usage of social media platforms like Facebook. For instance, when students overspend their time into Facebook usage, they are likely to face mental illness something which may interfere with their engagement in learning. The study of Nisar, Prabhakar, Ilavarasan and Baabdullah (2019), for instance, was conducted using data collected through an online survey of 399 Facebook users in the UK, whereby a Facebook frequency rating scale was developed and validated as a part of the study. The findings indicate a negative relationship between active Facebook usage and mental health. Particularly, increased depressive symptoms were identified among active Facebook users. Similarly, the study of Hanprathet, Manwong, Khumsri, Yingyeun and Phanasathit (2015) found that Facebook addiction among high school students is associated with abnormal general mental health status, somatic symptoms, anxiety and insomnia, social dysfunction, and severe depression. With these findings, they recommended that relevant authorities must educate young people about the mental health impacts linked with Facebook addictive usage.

\section{METHODOLOGY AND DESIGN OF THE RESEARCH}

This section dealt with a research methodology that guided the study. It outlines the research design employed, population and sampling procedures, data collection method and procedures as well as validity and reliability of research instruments. 


\section{Research Design}

The study employed descriptive correlational research design in the sense that the first three research questions simply described perception of respondents while the last research question sought to establish the interrelationships among variables under investigation. According to Mugenda and Mugenda (2003) descriptive design entails a systematic and empirical inquiry in which the researcher describes certain aspects and establishes how the independent variable affects the dependent variable.

\section{Population, Sampling and Data Collection Method}

One of the key limitations of the study was the fact that students under investigation would not be reached physically to fill the questionnaire due to the Corona Virus Pandemic which made it not possible to contact respondents physically.

Table 1. Demographic Characteristics of Respondents

\begin{tabular}{|c|c|c|c|}
\hline SN & Category & Frequency & Percent \\
\hline \multirow[t]{4}{*}{1.} & Gender of Respondents & & \\
\hline & Males & 50 & 19.8 \\
\hline & Females & 203 & 80.2 \\
\hline & TOTAL & 253 & 100 \\
\hline \multirow[t]{4}{*}{2.} & Study Level & & \\
\hline & S1 & 241 & 95.3 \\
\hline & S2and 3 & 12 & 4.7 \\
\hline & TOTAL & 253 & 100 \\
\hline \multirow[t]{4}{*}{3} & Age of respondents & & \\
\hline & 22 and below & 221 & 87.4 \\
\hline & 23 and above & 32 & 12.6 \\
\hline & TOTAL & 253 & 100 \\
\hline \multirow[t]{4}{*}{4} & Type of university & & \\
\hline & State university & 62 & 24.5 \\
\hline & Private university & 191 & 75.5 \\
\hline & TOTAL & 253 & 100 \\
\hline \multirow[t]{4}{*}{5} & Marital & & \\
\hline & Single & 233 & 92.1 \\
\hline & Married & 20 & 7.9 \\
\hline & TOTAL & 253 & 100 \\
\hline \multirow[t]{5}{*}{6} & Race & & \\
\hline & Javanese & 217 & 85.8 \\
\hline & Madurese & 18 & 7.1 \\
\hline & Other & 18 & 7.1 \\
\hline & TOTAL & 253 & 100 \\
\hline \multirow[t]{5}{*}{7.} & Area of Study & & \\
\hline & Exact Science & 107 & 42.3 \\
\hline & Social Science & 115 & 45.5 \\
\hline & Linguistics & 31 & 12.3 \\
\hline & TOTAL & 253 & 100 \\
\hline
\end{tabular}

To overcome this threat, the questionnaire was sent online to potential respondents in selected universities to read and fill it. Out of 300 expected respondents, 253 managed to fill and return the questionnaire, thus the 
response rate was $84.3 \%$. Questionnaire was the only tool used to gather data from respondents. It was selfconstructed by the researchers based on reviewed literature and studies. The questionnaire had two major sections namely demographic characteristics of respondents and descriptive section whereby respondents were to tick the most predetermined most correct perception. Description of questionnaire respondents by demographic characteristics appears in table 1.

In terms of gender, males were $50(19.8 \%)$ while females were 203 (80.2\%). Therefore, majority of respondents were females. By study level, S1 students were 241 (95.3\%) while S2 and S3 were 12 (4.7\%). Therefore, majority of respondents were $S 1$ students. Respondents were also categorized according to their age groups. Those in the group of 22 years and below were 221 (87.4\%) while those 23 and above were $32(12.6 \%)$ meaning that majority of respondents were in the age of 22 years and below. As far as type of university is concerned, 62 (24.5\%) came from State Universities while 191 (75.5\%) came from Public Universities. Therefore, majority of respondents came from private universities. A total of 233 (92.1\%) were single while $20(7.9 \%)$ were married. Therefore, majority of respondents were single as compared to married counterparts. As far as race is concerned, $217(85.8 \%)$ respondents were from the Javanese race while 18 (7.1\%) came from the Madurese race and 18 (7.1\%) came from other races. Therefore, majority of respondents came from the Javanese race. Finally, respondents were characterized according to area of study. In this demographic factor, 107 (42.3\%) took exact science, 115 (45.2\%) took social sciences while $31(12.3 \%)$ took linguistics. Therefore, majority took social sciences.

\section{Validity and Reliability}

Prior to data analysis, the questionnaire was subjected to pilot testing to determine internal consistency of items. SPSS was used to calculate Cronbach's Alpha for each variable in the questionnaire and minimal acceptable reliability was 0.7 .

Table 2. Reliability Test

\begin{tabular}{cccc}
\hline SN & Variable in Question & Items & Cronbach's Alpha \\
1. & Facebook Use & 9 & .842 \\
2. & Mental Health & 11 & .752 \\
3. & Engagement in Learning & 11 & .759 \\
\hline
\end{tabular}

As seen in Table 2, Cronbach's Alpha for Facebook use was .842, for mental health was .752 and for engagement in learning was .759 meaning internal consistency of items in the questionnaire was good enough.

\section{DATA ANALYSIS AND RESULTS}

Analysis of data included descriptive statistics and correlational analysis among the variables of interest. The descriptive analysis involved mean scores and standard deviations in various aspects while the correlational analysis, on the other hand, involved hypothesis testing to determine the interrelationships among variables under investigation.

\section{Descriptive Analysis of Data}

This section sought to establish perception of students on Facebook use for learning, mental health and engagement in learning. Students were required to respond by ticking most appropriate option in the questionnaire ranging from 4- strongly agree, 3- agree, 2- disagree and 1- strongly disagree. Scale of mean score interpretation was as follows: $3.50-4.00=$ strongly agree, $2.50-3.49=$ agree, $1.50-2.49=$ disagree and $1.00-1.49$ = strongly disagree. 
Research Question One: What is the perception of University students in Subaraya City on Facebook use for learning?

This research question sought to establish perception of students on the use of Facebook platform for learning. There were nine items in the questionnaire whereby students were to indicate their level of agreement or disagreement with particular statements. As observed in Table 3, mean score for the first three items in the questionnaire ranged between 2.50 and 3.49 which means agreement with the statement. Particularly, students generally agreed that they have Facebook accounts, they have many friends with whom they are connected through Facebook platform and that they possess devices that support the use of Facebook. This suggests that students in selected universities are well equipped with Facebook devices. This finding is in harmony with the Internet World State (2018) which describes Indonesia as the $4^{\text {th }}$ country in the world with the highest Facebook user having 130 million users.

Table 3. Perception of Students on Facebook Use

\begin{tabular}{clccc}
\hline SN & \multicolumn{1}{c}{ Item } & Mean & Std. Dev & Interpretation \\
\hline 1. & I have a Facebook account & 2.97 & .63248 & Agree \\
2. & I have many friends from Facebook & 2.65 & .75433 & Agree \\
3. $\quad$ I possess a devise that supports the use of Facebook & 2.51 & .57594 & Agree \\
4. & Facebook is a valuable platform for effective learning & 2.27 & .58633 & Disagree \\
5. & Facebook is one of major social media platforms to depend & 2.17 & .70246 & Disagree \\
6. I frequently log in Facebook whenever I am on my phone/ computer & 2.08 & .74869 & Disagree \\
7. I usually provide information via Facebook to support peer learning & 1.88 & .62502 & Disagree \\
8. I participate in the course-related peer discussion via Facebook. & 1.86 & .58902 & Disagree \\
9. I cannot finish a day without visiting Facebook & 1.73 & .70930 & Disagree \\
\hline
\end{tabular}

However, mean score for the last six items in Table 3 was between 1.50 and 2.49 which denotes disagreement. Particularly, students disagreed that Facebook is a valuable platform for effective learning, that Facebook is one of major social media platforms to depend on and that they frequently log in Facebook whenever they are on their phones or related devices. Furthermore, they disagreed that they usually provide information via Facebook to support peer learning, that they participate in the course-related peer discussion via Facebook and that they cannot finish a day without visiting Facebook. Much as students were well equipped with gadgets for Facebook usage, they actually did not use the platform for the learning process. When asked to list type of social media platforms used in day to day life, the most frequently mentioned platform was Instagram (57.3\%) followed by WhatsApp (28.5\%), Twitter (7.1\%), Facebook (5.1\%) and others (2\%). This finding is in harmony with that of Inayati (2015)Malang, Indonesia. She obtained her Master of Education from the University of Adelaide, Australia. She has published several textbooks and research papers, and presented in several conferences. Her research interest is in technology and independent learning in ELT. Social media technology (SMT that although most faculty members in Indonesia were aware of the benefit Facebook in teaching and learning, they are reluctant to use it in the classroom. Specifically, when they were asked to list the social media platforms used for learning, Google Classroom was the most frequently listed (50.6\%) followed by WhatsApp (30.8\%) and Zoom (18.6). Therefore, Facebook is not preferred platform for learning. Therefore, Facebook was not preferred by students for learning.

Research Question Two: What is the perception of University students in Subaraya City on their Mental Health?

The second research question sought to establish mental health of students under investigation as appears in Table 4. Information from the table indicates that mean score for the first two items ranged between 1.50 
and 2.49 which denotes disagreement with the statements. Particularly, students disagreed that their minds are free from anxiety and that it is easy for them to cope up with stressful moments. Therefore, students under investigations were faced with anxiety and it was difficult for them to cope up with the anxiety they went through. This situation might be due to the Covid 19 outbreak which was seriously facing Indonesia during the time of data collection to the extent that educational institutions were closed, and students filled the questionnaire online.

Table 4. Perception of Students on their Mental Health

\begin{tabular}{clccc}
\hline SN & \multicolumn{1}{c}{ Item } & Mean & Std. Dev & Interpretation \\
\hline 1. & My mind if free from anxiety & 2.42 & .67229 & Disagree \\
2. & It is easy for me to cope up with stressful moments & 2.37 & .65261 & Disagree \\
3. $\quad$ I normally feel calm and peaceful & 2.62 & .66391 & Agree \\
4. $\quad$ I rarely feel down, depressed, or hopeless. & 2.67 & .71206 & Agree \\
5. $\quad$ Under pressure, I stay focused and think clearly. & 2.75 & .64946 & Agree \\
6. Inormally see the humorous side whenever faced with difficulties & 2.85 & .62230 & Agree \\
7. I am able to adapt when changes occur in my life & 2.91 & .54948 & Agree \\
8. $\quad$ Even when things look hopeless, I don't give up easily & 3.07 & .56596 & Agree \\
9. I am strong when dealing with life's challenges and difficulties & 3.10 & .53943 & Agree \\
10. I am not easily discouraged by failure & 3.10 & .54233 & Agree \\
11. I normally have interest and pleasure in doing things & 3.18 & .44381 & Agree \\
\hline
\end{tabular}

While mental health disorders can influence violence and crime cases in the society (Halle et al., 2020), this situation calls for effective strategies to combat the anxious moments students went through. As suggested by deJonge, Omran, Faulkner and Sabiston (2020), experienced anxiety can be combated through various ways including active involvement in physical exercises as well as effective guidance and counseling. Therefore, the guidance and counseling experts from universities in Subaraya City should counsel students to engage into physical exercises while taking preventive measures against the Covid 19 which is a global pandemic.

However, it is worth noting that amid stressful moments students were going through, the mean score for the rest of items in Table four ranged between 2.50 and 3.49, suggesting agreement with the statements. Particularly, students agreed that they normally feel calm and peaceful. This suggests that their studying environments are supportive enough to create peaceful atmosphere for learning in spite of stressful moments. Furthermore, they agreed that they rarely feel down, depressed or hopeless and that when under pressure, they stay focused and think clearly. They also agreed that they normally see humorous side whenever faced with difficulties, they are able to adopt when changes occur in their lives and they don't give up easily even when things look helpless. Finally, they agreed that they are strong when dealing with life challenges and difficulties, they are not easily discouraged by failure and they normally have interest and pleasure in doing things.

Research Question Three: What is the perception of University students in Surabaya City on their engagement in learning?

While active engagement is a key factor for learning effective, the third research question sought to determine the extent to which learners got engaged in the learning process. There were eleven items in the questionnaire to which they had to show their level of agreement or disagreement. As observed in table 5, the mean score for all items ranged between 2.50 and 3.49 suggesting agreement with all the items. Particularly, students agreed that their minds concentrate in learning without any interference from Facebook. 
Table 5. Students' Engagement in Learning

\begin{tabular}{clccc}
\hline SN & \multicolumn{1}{c}{ Item } & Mean & Std. Dev & Interpretation \\
\hline 1. & My mind concentrates in learning without interference from Facebook & 2.69 & .65938 & Agree \\
2. & I take active role in extra-curricular activities at the university & 2.72 & .66123 & Agree \\
3. & I actively participate in school activities like sports and game & 2.73 & .61632 & Agree \\
4. & It is easy to concentrate during the teaching-learning session & 2.77 & .54974 & Agree \\
5. I I am comfortable to stay in class while teaching - learning takes place & 2.98 & .45845 & Agree \\
6. & When I'm in class, I participate in learning activities & 2.99 & .51561 & Agree \\
7. I Iactively engage in the teaching-learning process & 3.01 & .49986 & Agree \\
8. & What I learn in class is interesting & 3.03 & .49443 & Agree \\
9. I pay undivided attention to what should take place in class & 3.16 & .49744 & Agree \\
10. I am able to control FB use not to interfere with studies in class & 3.22 & .81066 & Agree \\
11. I never check on Facebook while in class & 3.35 & .70223 & Agree \\
\hline
\end{tabular}

They also agreed that they take role in extra-curricular activities at their respective universities and particularly in sports and games. Also it was easy for them to concentrate during the learning sessions. Furthermore, they agreed that they were comfortable to stay in class while teaching-learning takes place and actually they actively participated in the teaching and learning process. Finally, they agreed that what they learnt in class was interesting, they paid undivided attention to what should take place in classrooms, they were able to control FB use not to interfere with their studies and they never check on FB while in class. This means that while learning in classrooms, they are not tempted to open their devices to read Facebook notifications. The fact that students do not access Facebook during the teaching-learning session would also mean that Facebook is not used for teaching and learning. This finding is similar to that of Jha, Shah, Basnet, et al (2016), who investigated on Facebook use and its effects on the life of health science students in Nepal and found out that the main reason for using Facebook was to remain in contact with family and friend (32\%) while its use for the academic purpose was only $5 \%$.

\section{Hypothesis Testing}

This section dealt with hypothesis testing to determine the interrelationship among variables under investigation, it was deemed necessary to test null hypotheses which resulted from the next three research questions.

Research Question Four: Is there significant difference in Facebook use by students characterized according to gender and area of study?

Table 6. Facebook Use by Gender

Hypothesis Test Summary

\begin{tabular}{|llll|}
\hline \multicolumn{1}{|c}{ Null Hypothesis } & \multicolumn{1}{c}{ Test } & Sig. & Decision \\
\hline & $\begin{array}{l}\text { Independent- } \\
\text { Samples }\end{array}$ & \\
$\begin{array}{l}\text { The distribution of } \\
\text { FACEBOOKfactor is the same } \\
\text { across categories of Gender. }\end{array}$ & $\begin{array}{l}\text { Mann- } \\
\text { Whitney U } \\
\text { Test }\end{array}$ & $.054 \begin{array}{l}\text { Rull } \\
\text { hypothesis. }\end{array}$ \\
\end{tabular}

Asymptotic significances are displayed. The significance level is 05

As observed in results of the first research question that Facebook was not a preferred platform for learning by students, it was necessary to test a hypothesis to determine Facebook use by students' gender and area of study. The question called for testing for a hypothesis which states: There is no significant difference in Facebook use by students characterized according to gender and area of study. Table 6 indicates the Independent Sample Mann-Whitney U Test with a Sig. of .54 which is greater than the critical value (.05) suggesting that the difference in the use of Facebook by Gender does not exist. 
Table 7. Facebook Use by Area of Study

\begin{tabular}{cccc}
\hline Area of Study & Mean Score & Sig. & Results \\
\hline Linguistics and Social Sciences & 2.26 & .142 & No significant difference \\
Exact Sciences & 2.18 & & \\
\hline
\end{tabular}

Furthermore, Table 7 indicates the Independent Sample T- test with mean score of 2.26 for linguistics and Social Sciences and 2.81 for exact sciences and the Sig. of .142 which is greater than the critical value (.05), suggesting the difference in the use of Facebook by area of study happens by chance and therefore, not significant. Therefore, the null hypothesis is accepted that there is no significant difference in Facebook use by students characterized according to gender and area of study.

Research Question Five: Is there significant relationship between Facebook use, mental health and engagement in learning by university students in Surabaya City?

This research question called to testing a null hypothesis which states: there is no significant relationship between Facebook use, mental health and engagement in learning by university students in Surabaya City. The null hypothesis was tested through Pearson Product Moment Correlation Coefficient within the Statistical Package for Social Sciences. The strength of possible correlations was interpreted as follows: Greater or Equal to $0.7=$ Strong Relationship; Greater or Equal to $0.5=$ Moderate Relationship and lesser or Equal to $0.5=$ Weak Relationship.

Table 8. Correlation among Variables

\begin{tabular}{llccc}
\hline & & Mental Health & Engagement & Facebook Use \\
Mental Health & Pearson Correlation & 1 & $.394^{* *}$ & $.212^{* * *}$ \\
& Sig. (2-tailed) & & .000 & .001 \\
\multirow{2}{*}{ Engagement } & $\mathrm{N}$ & 253 & 253 & 253 \\
& Pearson Correlation & $.394^{* *}$ & 1 & -.041 \\
& Sig. (2-tailed) & .000 & & .514 \\
\multirow{2}{*}{ Facebook Use } & $\mathrm{N}$ & 253 & 253 & 1 \\
& Pearson Correlation & $.212^{* *}$ & -.041 & 253 \\
\hline **. Correlation is significant at the 0.01 level (2-tailed). & .001 & .514 & 253 \\
\hline
\end{tabular}

As seen in Table 8, there is a significant weak yet positive correlation between mental health and engagement in learning $(\mathrm{r}=.394, p=.000)$. The positive correlation means mental health positively influences the rate of students' engagement in learning. This finding is supported by existing literature and study findings. According to Jonynien and Kern (2012) in Alhabees, Alsaida and Alhabees (2018), mental health is a state of psychological contentment or the condition when there is no mental illness. It is a psychological state for learners to function at a satisfactory level of emotional and behavioral adjustment. This means mental health propels learners to function properly in various aspects including learning engagement. Therefore, the more the mental health, the more the engagement in the learning process.

Secondly, there is a significant weak yet positive correlation between Facebook usage and mental health $(\mathrm{r}=.212, p=.001)$. The positive correlation means Facebook usage positively influences mental health. This finding is contrary to findings of Nisar, Prabhakar, Ilavarasan and Baabdullah (2019) who conducted a similar study using data collected through an online survey of 399 Facebook users in the UK, where a negative relationship existed between active Facebook usage and mental health and increased depressive symptoms were identified among active Facebook users. While other studies like that of Hanprathet, 
Manwong, Khumsri, Yingyeun and Phanasathit (2015) found that Facebook addiction is associated with abnormal general mental health, somatic symptoms, anxiety and insomnia, there is need for students to make use of Facebook moderately to avoid negative effects of the overuse of Facebook.

\section{CONCLUSIONS AND RECOMMENDATIONS}

This section comes up with conclusions and then gives corresponding recommendations to students, parents, educators and other education stakeholders with regard to Facebook use, mental health and engagement in learning.

\section{Conclusions of the Study}

The researchers came up with the following conclusions of the study: First, whereas students were well equipped with devices for Facebook, they had Facebook accounts and many friends with whom they are connected through platform, they did not consider Facebook as a valuable platform for effective learning. They neither provided information through Facebook to support peer learning nor did they participate in the course-related peer discussions through Facebook. There is no significant difference in use of Facebook by gender and areas of study. Students' most preferred social media platforms for learning include Google classroom (50.6\%), WhatsApp Group (30.8\%) and Zoom (18.6\%) in order of preference.

Secondly, students experienced anxiety and it was not easy not for them to cope up with stressful moments they went through. This might be due to the Covid 19 outbreak which was seriously facing Indonesia during the time of data collection. Yet they felt calm and peaceful, they stayed focused, thought clearly and saw humorous side whenever faced with difficulties.

Thirdly, students concentrated in learning without any interference from Facebook. They took active role in extra-curricular activities and engaged in sports and games. They were comfortable to stay in class while teaching-learning took place and therefore were highly engaged in the learning process. They considered what they learnt in class interesting and paid undivided attention to what took place in classrooms.

Lastly, there is a significant weak yet positive correlation between mental health and engagement in learning and between Facebook use and mental health. Therefore, mental health influences the rate of students' engagement in learning positively while Facebook use enhances mental health.

\section{Recommendations of the Study}

Based on conclusions above, the researchers came up with the following recommendations to students, parents and other education stakeholders:

First, educators in higher learning institutions, especially in Surabaya City, should make good use of Google Classroom, WhatsApp and Zoom to support students' engagement in learning especially during this critical time for Global Covid 19 pandemic when online learning is needed than ever before. Facebook can be used as an alternative instructional media for those students who may prefer using it for learning. There is need to encourage students to frequently and actively participate in sports and games for them to overcome stressful moments they go through. Furthermore, face to face or online guidance and counseling are highly needed to help those students who go through critical stressful moments for them to come back to their normal health conditions and proceed with active engagement in learning.

In addition, educators should take advantage of students' readiness to actively engage in the teaching-learning processes by introducing alternative social media platforms for enhancement of learning engagement as revealed by de Paulo, Sinatra, Monacis, Di Bitonto, Roselli (2012) who advocated for the efficacy of the adaptation of learning contents to students' cognitive style in an e-learning setting, centrally to what happens routinely, and Bitonto, Roselli, Rossano, Sinatra (2009) who believed in customizing learning paths according to user preferences based on the fact that individuals learn best when information is presented in ways that are congruent with learners' preference.

Finally, University administration teams, educators and parents should work together to enhance mental health education and support to increase rates of students' engagement in learning. Furthermore, there is need to encourage students to get connected with friends and peer learners through Facebook and other social media platforms as engagement in such improves mental health. 


\section{BIODATA and CONTACT ADDRESSES of AUTHORS}

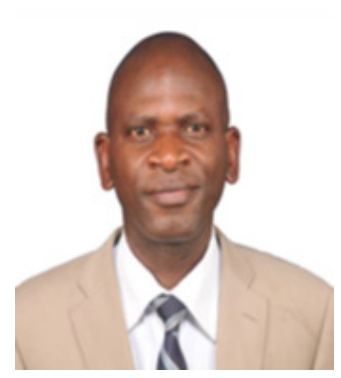

Dr. Baraka Manjale NGUSSA, PhD, is an Associate Professor of Curriculum and Teaching at the University of Arusha in Tanzania. He completed his PhD in Education (Curriculum and Teaching) from the University of Eastern Africa Baraton in Kenya in 2016. He has a wide experience in teaching, publication and research supervision. He has authored over 50 publications including books, journal articles encyclopedia articles and book chapters. His research areas includes curriculum and teaching, educational management and leadership as well as research in higher education. He is an external examiner of University of South Africa and University of Eastern Africa Baraton, Kenya.

Baraka Manjale NGUSSA

Department of Curriculum and Teaching, School of Education, University of Arusha.

Address: P. O. Box 7 Usa River, Arusha, Tanzania

Phone: +255753889912

E-mail: ngussathe5th@gmail.com

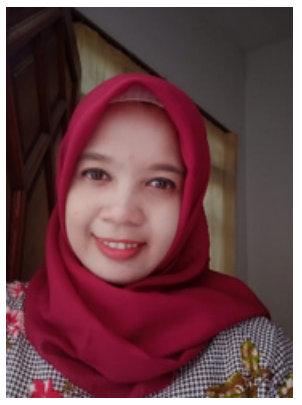

Fifi Khoirul FITRIYAH, is a lecturer at the Faculty of Teacher Training and Education, Universitas Nahdlatul Ulama Surabaya. She gained her Master Degree in Department of Guidance and Counseling, Universitas Pendidikan Indonesia in 2014. She is currently working on Ph.D program at the Department of Guidance and Counseling, Universitas Negeri Malang, Indonesia. Her academic interest areas are cultural counseling, mental health, learning and education. She has more than 19 articles published in national and international journals with reputable indexing.

Fifi Khoirul FITRIYAH

Department of Early Childhood Education, Faculty of Teacher Training and Education

Address: UNUSA Kampus B, Jl. Raya Jemursari No.57, Jemur Wonosari, Kec. Wonocolo, 60237, Surabaya, Indonesia

Phone: +6281312294102

E-mail: fifi@unusa.ac.id

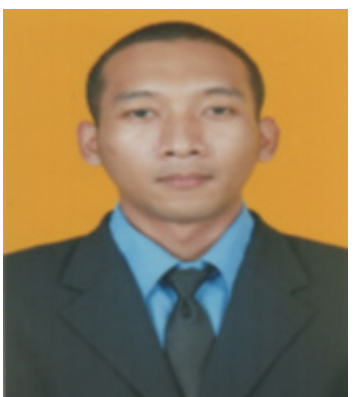

Syaiputra Wahyuda Meisa DININGRAT, is a lecturer in the Department of Islamic Early Childhood Education, STIT Al-Ibrohimy Bangkalan, Indonesia. He received his Master in Educational Technology from Universitas Negeri Surabaya at September, 2016. His main research areas of interest are Issues in TechnologyEnhanced Learning, Online Learning, Flipped Classroom and Instructional Design. Syaiputra Wahyuda Meisa Diningrat Has been teaching instructional technology for early childhood learners for the last5 years. He has more than 3 articles published in international journals. He is currently pursuing his $\mathrm{PhD}$ in Instructional Technology which has strong focus in computational thinking, flipped classroom, and instructional videos.

Syaiputra Wahyuda Meisa DININGRAT

Department of Islamic Early Childhood Education

Address: STIT Al-Ibrohimy Bangkalan,

Jl. Raya Galis No.03 Galis, Bangkalan, East Java 69173, Indonesia

Phone: 0823-3147-4019

E-mail: syaiputradiningrat@stital.ac.id 


\section{REFERENCES}

Alhabees, F. A., Alsaida, K. A. and Alhabees, K. A. M. (2018). Levels of Mental Health among University Students: A Comparative Study Between Public and Private University. Journal of Education and Practice 9(10), 39-44.

Al-Khalifa, H. S., \& Garcia, R. A. (2013). The State of Social Media in Saudi Arabia's Higher Education. International Journal of Technology and Educational Marketing, 3(1), 65-76. https://doi. org/10.4018/ijtem.2013010105

Al-rahmi, W. M. (2013). The Impact of Social Media use on Academic Performance among university students : A Pilot Study. Journal Of Information Systems Research and Innovation, (July 2017), 1-10. https://doi.org/http://seminar.utmspace.edu.my/jisri/

Alrashidi, O., Phan, H. P., \& Ngu, B. H. (2016). Academic Engagement: An Overview of Its Definitions, Dimensions, and Major Conceptualisations. International Education Studies, 9(12), 41. https:// doi.org/10.5539/ies.v9n12p41

Avendano, M., de Coulon, A., \& Nafilyan, V. (2020). Does longer compulsory schooling affect mental health? Evidence from a British reform. Journal of Public Economics, 183, 104137. https://doi. org/10.1016/j.jpubeco.2020.104137

Baggaley, J. (2012). Harmonizing global education: From Genghis Khan to Facebook. Harmonizing Global Education: From Genghis Khan to Facebook, (October), 1-197. https://doi. org/10.4324/9780203817636

Brailovskaia, J., Margraf, J., Schillack, H., \& Kollner, V. (2019). Comparing mental health of Facebook users and Facebook non-users in an inpatient sample in Germany. Journal of Affective Disorders, 259(April), 376-381. https://doi.org/10.1016/j.jad.2019.08.078

Bitonto, D., Roselli, T., Rossano, V., Sinatra, M. (2009). Adaptive learning using SCORM compliant resources. International Conference on Distributed Multimedia Systems. From https://www.researchgate.net/ search.Search.html?type=publication\&query=Adaptive $\% 20$ learning\%20using\%20SCORM\%20 compliant\%20resources.

Brooker, C., Hughes, E., Lloyd-Evans, B., \& Stefanidou, T. (2019). Mental health pathways from a sexual assault centre: A review of the literature. Journal of Forensic and Legal Medicine, 68(August), 101862. https://doi.org/10.1016/j.jflm.2019.101862

Burges, S. and Sievertses, H. H. (2020). Schools, skills, and learning: The impact of COVID-19 on education. Retrieved on April 5. 2020 from https://voxeu.org/article/impact-covid-19-education

Castelpietra, G., Nicotra, A., Pischiutta, L., Gutierrez-Colosía, M. R., Haro, J. M., \& Salvador-Carulla, L. (2020). The new Horizon Europe programme 2021-2028: Should the gap between the burden of mental disorders and the funding of mental health research be filled? European Journal of Psychiatry, 34(1), 44-46. https://doi.org/10.1016/j.ejpsy.2019.12.001

deJonge, M. L., Omran, J., Faulkner, G. E., \& Sabiston, C. M. (2020). University students' and clinicians' beliefs and attitudes towards physical activity for mental health. Mental Health and Physical Activity, 18(December 2019), 100316. https://doi.org/10.1016/j.mhpa.2019.100316

de Paulo, V., Sinatra, M., Monacis, G., Di Bitonto, P., Roselli, T, (2012). How cognitive styles affect the e-learning process. 12th IEEE International Conference on Advanced Learning Technologies. From https://ieeexplore.ieee.org/document/6268119

Dixon De Silva, L. E., Ponting, C., Ramos, G., Cornejo Guevara, M. V., \& Chavira, D. A. (2020). Urban Latinx parents' attitudes towards mental health: Mental health literacy and service use. Children and Youth Services Review, 109, 104719. https://doi.org/10.1016/j.childyouth.2019.104719

Frankham, C., Richardson, T., \& Maguire, N. (2020). Psychological factors associated with financial hardship and mental health: A systematic review. Clinical Psychology Review, 77, 101832. https:// doi.org/10.1016/j.cpr.2020.101832

Fredricks, J., \& McColskey, W. (2012). The Measurement of Student Engagement: A Comparative Analysis of Various Methods and Student Self-report Instruments. In Handbook of Research on Student Engagement. https://doi.org/10.1007/978-1-4614-2018-7 
Fusar-poli, P., Salazar, G., Pablo, D., Micheli, A. De, Nieman, D. H., Correll, C. U., ... Amelsvoort, T. Van. (2019). What is good mental health ? A scoping review. European Neuropsychopharmacology, 1-14. https://doi.org/10.1016/j.euroneuro.2019.12.105

Halle, C., Tzani-Pepelasi, C., Pylarinou, N. R., \& Fumagalli, A. (2020). The link between mental health, crime and violence. New Ideas in Psychology, 58(December 2019), 100779. https://doi.org/10.1016/j. newideapsych.2020.100779

Hart, S., Stewart, K., Jimson, S. R. (2011). The Student Engagement in Schools Questionnaire (SESQ) and the Teacher Engagement Report Form-New (TERF-N): Examining the Preliminary Evidence. Contemporary School Psychology 2011(15), 67-79.

Inayati, N. (2015). English language teachers' use of social media technology in Indonesian higher education context. Asian EFL Journal, 17(4), 6-36.

Lenandlar, S. (2013). Guided assessment or open discourse: A comparative analysis of students interaction on facebook groups. Turkish Online Journal of Distance Education, 14(1), 35-43.

Lim, T. (2010). The use of facebook for online discussions among distance learners. Turkish Online Journal of Distance Education, 11(4), 72-81. https://doi.org/10.17718/tojde.17195

Lindow, J. C., Hughes, J. L., South, C., Minhajuddin, A., Gutierrez, L., Bannister, E., ... Byerly, M. J. (2020). The Youth Aware of Mental Health Intervention: Impact on Help Seeking, Mental Health Knowledge, and Stigma in U.S. Adolescents. Journal of Adolescent Health. https://doi. org/10.1016/j.jadohealth.2020.01.006

Lowe, J. (2020). Social Science \& Medicine Power, powerlessness and the politics of mobility: Reconsidering mental health geographies. Social Science \& Medicine, 252(October 2019). https:// doi.org/10.1016/j.socscimed.2020.112918

Martin, F. and Boliger, D. U. (2018). Engagement Matters: Perceptions on the importance of engagement strategies in the Online learning Environment. Online Learning Journal 22(1), 205-222.

Mirembe, D. P., Lubega, J. T., \& Kibukamusoke, M. (2020). Leveraging Social Media in Higher Education: A Case of Universities in Uganda. European Journal of Open, Distance and E-Learning, 22(1), 70-84. https://doi.org/10.2478/eurodl-2019-0005

Ngussa, B. M., and Abel, C. (2017). Significance and adequacy of instructional media as perceived by primary school pupils and teachers in Kinondoni District, Tanzania. International Journal of Educational Policy Research and Review, 4 (6), 151-157.

Ngussa, B. M., and Ndiku, L.M (2014). Constructivism Experiences in Teaching-Learning Transaction among Adventist Secondary Schools in South Nyanza, Tanzania. American Journal of Educational Research 2(11A), 1-7.

Nasional Survey of Student Engagement. (2002). From promise to progress: How colleges and universities are using student engagement results to improve collegiate quality. Blomington: Indiana University, Center for Postsecodndary research and planning.

Patahuddin, S. M., Rokhmah, S., \& Lowrie, T. (2020). Indonesian Mathematics Teachers' and Educators' Perspectives on Social Media Platforms: The Case of Educational Facebook Groups. The AsiaPacific Education Researcher. https://doi.org/10.1007/s40299-020-00503-3

Petrea, I., Shields-zeeman, L., Keet, R., Nica, R., Kraan, K., Chihai, J., ... Consortium, M. (2019). Mental health system reform in Moldova: description of the program and reflections on its implementation between 2014 and 2019. Health Policy. https://doi.org/10.1016/j.healthpol.2019.11.007

Rafidiyah, D; Bayeck, R. Y. (2016). Social Media in English Teaching for Higher Education: The Case of Indonesia. (March 2016).

Rahman, A., and Ahmed, O. (2018). Facebook Use, Facebook Addiction and Mental Health of Chittagong University Students. Bulgarian Journal of Science and Education Policy (BJSEP) 12(2), 345-358. 
Robinson, J. D., Maslo, T. E., McKeirnan, K. C., Kim, A. P., \& Brand-Eubanks, D. C. (2020). The impact of a mental health course elective on student pharmacist attitudes. Currents in Pharmacy Teaching and Learning. https://doi.org/https://doi.org/10.1016/j.cptl.2020.02.011

Sharma, S. K., Joshi, A., \& Sharma, H. (2016). A multi-analytical approach to predict the Facebook usage in higher education. Computers in Human Behavior, 55, 340-353. https://doi.org/10.1016/j. chb.2015.09.020

Skinner, E. A., Kindermann, T. A., \& Furrer, C. J. (2009). A Motivational Perspective on Engagement and Disaffection. Educational and Psychological Measurement, 69(3), 493-525. https://doi. org/10.1177/0013164408323233

Taylor, L. and Pearson, J. (2011). Improving Student Engagement. Current Issues in Education, 14(1)1-34.

Wallace, D., \& Wang, X. (2020). SSM - Population Health Does in-prison physical and mental health impact recidivism ? SSM - Population Health, 11, 100569. https://doi.org/10.1016/j.ssmph.2020.100569

Xu, C., Gong, X., Fu, W., Xu, Y., Xu, H., Chen, W., \& Li, M. (2020). The role of career adaptability and resilience in mental health problems in Chinese adolescents. Children and Youth Services Review, 112, 104893. https://doi.org/10.1016/j.childyouth.2020.104893 